\title{
MPPGrows to Six Issues per Year in the Year 2004
}

The contribution of quality manuscripts has always been the backbone of $M P P$ and has led to the remarkable development of the journal.

It is just 1 year since $M P P$ gained recognition by being listed in Index Medicus/Medline and MPP abstracts are now also available in Spanish translation, which we hope will further broaden the readership of the papers. This is in addition to the worldwide exposure of papers as noted by the Doctor's Guide website (USA), where a significant number of our papers have been cited in their 'most read papers' lists within the last 12 months. Our colleagues have entrusted the proceedings of their conferences to $M P P$, leading to the publication of three supplement issues of the journal last year. Furthermore, the KFAS Prize for the best publication amongst Kuwaiti Scientific Journals was awarded to MPP in 2001.

You may have noticed the increase in the number of pages in this year's issues. This reflects a substantial increase in the number of manuscripts received by the journal, both from the local and international biomedical communities. It is noteworthy that the number of foreign manuscripts (from 37 different countries) is approaching $50 \%$ of the total submitted.

We are proud to announce that, from January 2004, MPP will appear as six issues per year. This important stage in the development of the journal will enable us to continue to fulfill our commitment to all our contributors. This will in no way compromise the quality of our journal and we will continue to strive to maintain the same high standards that we have set before.

The Editorial Board is most grateful for the support and encouragement of the publishing house of Karger in making these developments a reality.

We look forward to your further contributions in the next year.

Farida Al-Awadi

Editor in Chief

For the Editorial Board

\begin{tabular}{ll}
\hline KARGER & ○ 2004 S. Karger AG, Basel \\
$\begin{array}{l}\text { Fax +41 61 306 12 34 } \\
\begin{array}{l}\text { E-Mail karger@karger.ch } \\
\text { www.karger.com }\end{array}\end{array}$ & $\begin{array}{l}\text { Accessible online at: } \\
\text { www.karger.com/mpp }\end{array}$
\end{tabular}

